\title{
QUANTITATIVE ANTIBODY STUDIES IN MAN. I. THE EFFECT OF ADRENAL INSUFFICIENCY AND OF CORTISONE ON THE LEVEL OF CIRCULATING ANTIBODIES ${ }^{1}$
}

\author{
By DANIEL L. LARSON 2 AND LOIS J. TOMLINSON \\ (From the Department of Medicine of the College of Physicians and Surgeons, Columbia Uni- \\ versity and the Presbyterian Hospital, New York, N. Y.)
}

(Submitted for publication July 20, 1951; accepted August 20, 1951)

Investigators have for many years been interested in the relation of the adrenal gland to antibody formation. Observations made in animals have frequently led to conflicting results. The effect of adrenalectomy on antibody titres has been studied and has been shown to be associated with an elevation (1-3), a depression (4), and no change (5-8). The effect of ACTH or cortisone on antibody levels in the acute experiment has resulted in an elevation $(1,5,9-11)$, no change $(8$, 12), and a depression (13). The effect of ACTH or cortisone on antibody levels in the chronic experiment has resulted in an elevation (9), a depression $(14,15)$ and no change $(16,17)$. Observations in man on the effects of ACTH or cortisone on antibody levels have failed to demonstrate a change in either the acute (18-20) or chronic $(21,22)$ experiment. In previous studies on humans, antibody measurements have not been based on techniques which lend themselves to precise measurement. The purpose of this paper is to present observations on the effect of adrenal insufficiency and of cortisone administration on antibody titres in man using quantitative immunochemical techniques.

\section{MATERIALS AND METHODS}

The method of Heidelberger and MacPherson for the quantitative determination of precipitable antibody nitrogen was used throughout the experiments (23). Typespecific capsular polysaccharides of pneumococcus types I and II were used as antigens. Since complement and C-antibody may add nitrogen to specific precipitates (24, 25 ), these were removed before the analysis of the specific precipitates was carried out. Since heat inactivation may damage antibody present in low concentration (25), all sera were de-complemented with a system of crystalline ovalbumin and rabbit antiovalbumin serum. The

1 Aided by a grant from the American Cancer Society on recommendation of the National Research Council.

2 John and Mary R. Markle Scholar in Medical Science.
C-antibody was removed with C-polysaccharide derived from a type III or type VII pneumococcus. Results are expressed as micrograms of precipitable antibody nitrogen per 4 milliliters of serum. All materials were supplied through the generosity of Dr. Michael Heidelberger.

Individuals used in this study were from the hospital and clinic population of the Presbyterian Hospital. The patients used as controls were diagnosed as having peptic ulcer or arteriosclerotic heart disease. The five patients with adrenal insufficiency had the characteristic clinical and laboratory findings of Addison's disease. Desoxycorticosterone acetate was administered to four of the five patients during the test period. Although there is little evidence available in the literature, it has been shown that in animals DCA does not appear to influence antibody titres (10). The cortisone treated group were patients with rheumatoid arthritis receiving 200 milligrams of the drug by mouth three times each week. Cortisone treatment was started at least two weeks before immunization and was continued throughout the test period. No other medications were given. As an additional control group, eight patients with untreated rheumatoid arthritis were included in this study. ${ }^{3}$ Following a preliminary bleeding, each of the subjects was given 0.08 milligrams each of types I and II pneumococcus polysaccharides subcutaneously. Post-immunization bleedings were obtained at two and four weeks.

\section{RESULTS}

As can be seen from Table I, the 12 normal individuals exhibited responses similar to those observed by Heidelberger and associates $(25,26)$. C-antibody was present in all sera tested and there was no rise in the titres of C-antibody in spite of sizeable changes in antibody to the type-specific capsular polysaccharides. Pre-immunization antipolysaccharide titres were low or not detectable. Maximum antibody titres were usually achieved by two weeks after immunization. A good response to one antigen was not necessarily accompanied by a similar response to the other antigen.

8 Patients with arthritis used in this study were made available through the courtesy of Dr. Charles Ragan. 
TABLE I

Antibody formation in normal humans

\begin{tabular}{|c|c|c|c|}
\hline \multirow{2}{*}{ Subject } & \multirow{2}{*}{ Antibody to* } & \multicolumn{2}{|c|}{$\begin{array}{l}\text { Micrograms of antibody nitrogen } \\
\text { per } 4 \text { milliliters of serum }\end{array}$} \\
\hline & & $\begin{array}{l}\text { Pre-immuni- } \\
\text { zation }\end{array}$ & $\begin{array}{l}2 \text { weeks post- } \\
\text { immunization }\end{array}$ \\
\hline 1 & $\begin{array}{l}\text { C III } \\
\text { S I } \\
\text { S II }\end{array}$ & $\begin{array}{r}46 \\
3 \\
0\end{array}$ & $\begin{array}{l}28 \\
11 \\
11\end{array}$ \\
\hline 2 & $\begin{array}{l}\text { C III } \\
\text { S I } \\
\text { S II }\end{array}$ & $\begin{array}{r}21 \\
1 \\
1\end{array}$ & $\begin{array}{l}18 \\
27 \\
23\end{array}$ \\
\hline 3 & $\begin{array}{l}\text { C III } \\
\text { S I } \\
\text { S II }\end{array}$ & $\begin{array}{r}50 \\
4 \\
1\end{array}$ & $\begin{array}{l}57 \\
30 \\
23\end{array}$ \\
\hline 4 & $\begin{array}{l}\text { C III } \\
\text { S I } \\
\text { S II }\end{array}$ & $\begin{array}{l}7 \\
0 \\
1\end{array}$ & $\begin{array}{r}6 \\
29 \\
45\end{array}$ \\
\hline 6 & $\begin{array}{l}\text { C III } \\
\text { S I } \\
\text { S II }\end{array}$ & $\begin{array}{r}32 \\
0 \\
0\end{array}$ & $\begin{array}{r}25 \\
0 \\
6\end{array}$ \\
\hline 9 & $\begin{array}{l}\text { C III } \\
\text { S I } \\
\text { S II }\end{array}$ & $\begin{array}{r}18 \\
1 \\
0\end{array}$ & $\begin{array}{r}17 \\
4 \\
7\end{array}$ \\
\hline 11 & $\begin{array}{l}\text { C III } \\
\text { S I } \\
\text { S II }\end{array}$ & $\begin{array}{r}60 \\
1 \\
8\end{array}$ & $\begin{array}{l}62 \\
15 \\
24\end{array}$ \\
\hline 35 & $\begin{array}{l}\text { C III } \\
\text { S I } \\
\text { S II }\end{array}$ & $\begin{array}{l}7 \\
0 \\
0\end{array}$ & $\begin{array}{r}8 \\
52 \\
96\end{array}$ \\
\hline 39 & $\begin{array}{l}\text { C III } \\
\text { S I } \\
\text { S II }\end{array}$ & $\begin{array}{r}26 \\
0 \\
0\end{array}$ & $\begin{array}{l}26 \\
15 \\
22\end{array}$ \\
\hline 40 & $\begin{array}{l}\text { C III } \\
\text { S I } \\
\text { S II }\end{array}$ & $\begin{array}{r}39 \\
1 \\
3\end{array}$ & $\begin{array}{r}50 \\
144 \\
61\end{array}$ \\
\hline 41 & $\begin{array}{l}\text { C III } \\
\text { S I } \\
\text { S II }\end{array}$ & $\begin{array}{r}12 \\
0 \\
0\end{array}$ & $\begin{array}{r}8 \\
9 \\
19\end{array}$ \\
\hline 52 & $\begin{array}{l}\text { C III } \\
\text { S I } \\
\text { S II }\end{array}$ & $\begin{array}{r}33 \\
0 \\
2\end{array}$ & $\begin{array}{l}48 \\
22 \\
15\end{array}$ \\
\hline
\end{tabular}

* Letter and number refer to specific polysaccharide precipitinogen used.

Table II shows the data obtained on the antibody formation in five patients with adrenal insufficiency. It can be seen that there is no departure from the behavior of the control group.

In Table III data are presented on eight patients with untreated rheumatoid arthritis. It is apparent that the responses are similar to those observed in the group of controls. Table IV includes the figures for nine patients in the cortisone-
TABLE II

Antibody formation in patients with adrenal insufficiency

\begin{tabular}{|c|c|c|c|}
\hline \multirow{2}{*}{ Subject } & \multirow{2}{*}{ Antibody to* } & \multicolumn{2}{|c|}{$\begin{array}{l}\text { Micrograms of antibody nitrogen } \\
\text { per } 4 \text { milliliters of serum }\end{array}$} \\
\hline & & $\begin{array}{l}\text { Pre-immuni- } \\
\text { zation }\end{array}$ & $\begin{array}{l}2 \text { weeks post- } \\
\text { immunization }\end{array}$ \\
\hline 28 & $\begin{array}{l}\text { C III } \\
\text { S I } \\
\text { S II }\end{array}$ & $\begin{array}{r}10 \\
0 \\
1\end{array}$ & $\begin{array}{r}7 \\
25 \\
101\end{array}$ \\
\hline 29 & $\begin{array}{l}\text { C III } \\
\text { S I } \\
\text { S II }\end{array}$ & $\begin{array}{r}23 \\
0 \\
0\end{array}$ & $\begin{array}{l}32 \\
30 \\
39\end{array}$ \\
\hline 32 & $\begin{array}{l}\text { C III } \\
\text { S I } \\
\text { S II }\end{array}$ & $\begin{array}{r}20 \\
0 \\
0\end{array}$ & $\begin{array}{r}23 \\
7 \\
8\end{array}$ \\
\hline 37 & $\begin{array}{l}\text { C III } \\
\text { S I } \\
\text { S II }\end{array}$ & $\begin{array}{r}14 \\
0 \\
0\end{array}$ & $\begin{array}{r}9 \\
15 \\
26\end{array}$ \\
\hline 33 & $\begin{array}{l}\text { C III } \\
\text { S I } \\
\text { S II }\end{array}$ & $\begin{array}{r}11 \\
1 \\
.2\end{array}$ & $\begin{array}{r}5 \\
20 \\
22\end{array}$ \\
\hline
\end{tabular}

* Letter and number refer to the polysaccharide precipitinogen used.

treated group. There does not appear to be any impairment of antibody formation among those receiving cortisone, and, indeed, three of the nine patients demonstrated unusually high post-immunization titres.

Data are presented in Table $\mathrm{V}$ on two patients with rheumatoid arthritis who were immunized two weeks before the administration of cortisone. Patient No. 64 received 300 milligrams of cortisone and patient No. 67 received 200 milligrams of cortisone on the first day of treatment. Both patients were then given 100 milligrams of cortisone daily over the next four weeks. Antibody titres were determined at three hour intervals in the period immediately following the first dosage of cortisone as well as after four weeks of the drug. The data indicate that with the dosages used, cortisone exhibited no effect on previously elevated antibody titres.

\section{COMMENT}

Some of the conflicting evidence in the literature on the relation of adrenal activity to antibody levels may be resolved on the basis of species differences, as suggested by Mirick (21). Many of the results were obtained with techniques which do not permit direct comparison of the data from one 
TABLE III

Antibody formation in patients with untreated rheumatoid arthritis

\begin{tabular}{|c|c|c|c|c|}
\hline \multirow{3}{*}{ Subject } & \multirow{3}{*}{$\underset{\text { to* }}{\text { Antibody }}$} & \multicolumn{3}{|c|}{$\begin{array}{l}\text { Micrograms of antibody nitrogen } \\
\text { per } 4 \text { milliliters of serum }\end{array}$} \\
\hline & & \multirow{2}{*}{$\underset{\text { zation }}{\text { Pre-immu- }}$} & \multicolumn{2}{|c|}{ Post-immunization } \\
\hline & & & Two weeks & Four weeks \\
\hline 64 & $\begin{array}{l}\text { C VII } \\
\text { S I } \\
\text { S II }\end{array}$ & $\begin{array}{r}26 \\
0 \\
0\end{array}$ & $\begin{array}{l}49 \\
46 \\
56\end{array}$ & $t$ \\
\hline 67 & $\begin{array}{l}\text { C VII } \\
\text { S I } \\
\text { S II }\end{array}$ & $\begin{array}{r}38 \\
2 \\
2\end{array}$ & $\begin{array}{r}36 \\
2 \\
50\end{array}$ & $t$ \\
\hline 98 & $\begin{array}{l}\text { C VII } \\
\text { S I } \\
\text { S II }\end{array}$ & $\begin{array}{l}2 \\
0 \\
1\end{array}$ & $\begin{array}{r}4 \\
7 \\
17\end{array}$ & $\begin{array}{r}6 \\
7 \\
20\end{array}$ \\
\hline 99 & $\begin{array}{l}\text { C VII } \\
\text { S I } \\
\text { S II }\end{array}$ & $\begin{array}{r}10 \\
0 \\
0\end{array}$ & $\begin{array}{l}10 \\
22 \\
10\end{array}$ & $\begin{array}{l}10 \\
26 \\
12\end{array}$ \\
\hline 100 & $\begin{array}{l}\text { C VII } \\
\text { S I } \\
\text { S II }\end{array}$ & $\begin{array}{r}34 \\
4 \\
2\end{array}$ & $\begin{array}{l}39 \\
93 \\
13\end{array}$ & $\begin{array}{r}44 \\
146 \\
14\end{array}$ \\
\hline 101 & $\begin{array}{l}\text { C VII } \\
\text { S I } \\
\text { S II }\end{array}$ & $\begin{array}{r}97 \\
0 \\
0\end{array}$ & $\begin{array}{r}108 \\
3 \\
0\end{array}$ & $\begin{array}{r}92 \\
3 \\
2\end{array}$ \\
\hline 102 & $\begin{array}{l}\text { C VII } \\
\text { S I } \\
\text { S II }\end{array}$ & $\begin{array}{r}29 \\
1 \\
3\end{array}$ & $\begin{array}{l}35 \\
76 \\
23\end{array}$ & $\begin{array}{r}31 \\
112 \\
20\end{array}$ \\
\hline 103 & $\begin{array}{l}\text { C VII } \\
\text { S I } \\
\text { S II }\end{array}$ & $\begin{array}{r}13 \\
0 \\
0\end{array}$ & $\begin{array}{l}12 \\
18 \\
15\end{array}$ & $\begin{array}{l}12 \\
13 \\
17\end{array}$ \\
\hline
\end{tabular}

* Letter and number refer to the polysaccharide precipitinogen used.

† See Table V.

laboratory to another. Three groups of observers, however, using precise immunochemical techniques, have described the effect of cortisone and ACTH on antibody formation in the rabbit. DeVries reported the effect of a single dosage of 50 milligrams of ACTH on the titre of rabbit antiegg albumin in an acute experiment (13). Some of the animals were noted to have a significant drop in precipitable antibody nitrogen within nine hours, but as noted by the author, a serum dilution effect may have influenced the results. Germuth and Ottinger noted a striking decrease in rabbit antiegg albumin production when cortisone in dosage of 10 milligrams per day was administered concomitantly with the antigen (15). ACTH in dosage of 10 milligrams per day produced a similar but less marked effect. Bjфrneboe, Fischel, and
TABLE IV

Antibody formation in cortisone-treated patients with rheumatoid arthritis

\begin{tabular}{|c|c|c|c|c|}
\hline \multirow{3}{*}{ Subject } & \multirow{3}{*}{$\underset{\text { to* }}{\text { Antibody }}$} & \multicolumn{3}{|c|}{$\begin{array}{l}\text { Micrograms of antibody nitrogen } \\
\text { per } 4 \text { milliliters of serum }\end{array}$} \\
\hline & & \multirow{2}{*}{$\underset{\text { Pre-immu- }}{\text { nization }}$} & \multicolumn{2}{|c|}{ Post-immunization } \\
\hline & & & Two weeks & Four weeks \\
\hline 77 & $\begin{array}{l}\text { C VII } \\
\text { S I } \\
\text { S II }\end{array}$ & $\begin{array}{l}9 \\
1 \\
0\end{array}$ & $\begin{array}{r}16 \\
15 \\
120\end{array}$ & $\begin{array}{l}32 \\
20 \\
72\end{array}$ \\
\hline 78 & $\begin{array}{l}\text { C VII } \\
\text { S I } \\
\text { S II }\end{array}$ & $\begin{array}{r}25 \\
0 \\
0\end{array}$ & $\begin{array}{l}38 \\
67 \\
80\end{array}$ & $\begin{array}{l}34 \\
40 \\
65\end{array}$ \\
\hline 79 & $\begin{array}{l}\text { C VII } \\
\text { S I } \\
\text { S II }\end{array}$ & $\begin{array}{r}48 \\
0 \\
3\end{array}$ & $\begin{array}{l}41 \\
21 \\
22\end{array}$ & $\begin{array}{l}43 \\
27 \\
18\end{array}$ \\
\hline 87 & $\begin{array}{l}\text { C VII } \\
\text { S I } \\
\text { S II }\end{array}$ & $\begin{array}{l}7 \\
0 \\
0\end{array}$ & $\begin{array}{r}4 \\
0 \\
12\end{array}$ & $\begin{array}{r}42 \\
0 \\
18\end{array}$ \\
\hline 88 & $\begin{array}{l}\text { C VII } \\
\text { S I } \\
\text { S II }\end{array}$ & $\begin{array}{r}39 \\
0 \\
0\end{array}$ & $\begin{array}{r}61 \\
126 \\
110\end{array}$ & $\begin{array}{r}61 \\
113 \\
170\end{array}$ \\
\hline 89 & $\begin{array}{l}\text { C VII } \\
\text { S I } \\
\text { S II }\end{array}$ & $\begin{array}{r}14 \\
0 \\
0\end{array}$ & $\begin{array}{r}60 \\
0 \\
28\end{array}$ & $\begin{array}{r}10 \\
0 \\
35\end{array}$ \\
\hline 90 & $\begin{array}{l}\text { C VII } \\
\text { S I } \\
\text { S II }\end{array}$ & $\begin{array}{r}31 \\
0 \\
19\end{array}$ & $\begin{array}{l}53 \\
44 \\
36\end{array}$ & $\begin{array}{l}40 \\
38 \\
31\end{array}$ \\
\hline 91 & $\begin{array}{l}\text { C VII } \\
\text { S I } \\
\text { S II }\end{array}$ & $\begin{array}{r}14 \\
0 \\
4\end{array}$ & $\begin{array}{r}20 \\
89 \\
104\end{array}$ & $\begin{array}{r}21 \\
106 \\
156\end{array}$ \\
\hline 92 & $\begin{array}{l}\text { C VII } \\
\text { S I } \\
\text { S II }\end{array}$ & $\begin{array}{r}22 \\
3 \\
2\end{array}$ & $\begin{array}{r}26 \\
155 \\
116\end{array}$ & $\begin{array}{r}27 \\
196 \\
90\end{array}$ \\
\hline
\end{tabular}

* Letter and number refer to polysaccharide precipitinogen used.

Stoerk studied the production of polyvalent rabbit anti-pneumococcal serum using 10 milligrams per day of cortisone and up to 3 milligrams per day of ACTH (14). Their results were in agreement with those obtained by Germuth, although somewhat less dramatic. In addition, the effect was the same whether the drugs were given during the period of active immunization or to animals with previously elevated antibody titres. The dosages of cortisone used in the experiments on rabbits were considerably in excess of those used clinically when calculated on the basis of body weight.

There is evidence to suggest that the amount of antibody produced may be in part dependent upon 
TABLE V

Effect of cortisone on previously elevated antibody titers in two patients with rheumatoid arthritis

\begin{tabular}{c|c|c|c|c|c|c|c|c}
\hline \hline & & \multicolumn{6}{|c}{ Micrograms of antibody nitrogen per 4 milliliters of serum } \\
\cline { 3 - 8 } Subject & Antigen tof & & $\begin{array}{c}\text { Pre-immu- } \\
\text { nization }\end{array}$ & $\begin{array}{c}\text { 2 weeks post- } \\
\text { immunization }\end{array}$ & \multicolumn{5}{|c|}{ Time after cortisone } \\
\cline { 3 - 8 } & & & & 3 hrs. & 6 hrs. & 9 hrs. & 12 hrs. & 4 wks. \\
\hline $64^{*}$ & C VII & 26 & 49 & 49 & 48 & 48 & 31 & 35 \\
& S I & 0 & 46 & 48 & 45 & 43 & 43 & 37 \\
& S II & 0 & 56 & 63 & 59 & 56 & 50 & 52 \\
$67 \dagger$ & C VII & 38 & 36 & 43 & 31 & 35 & 34 & 20 \\
& S I & 2 & 2 & 2 & 1 & 2 & 3 & 6 \\
& S II & 0 & 50 & 57 & 54 & 56 & 52 & 44 \\
\hline
\end{tabular}

* Initial dosage cortisone $300 \mathrm{mg}$.

† Initial dosage cortisone $200 \mathrm{mg}$.

‡ Letter and number refer to polysaccharide precipitinogen used.

a local inflammatory reaction at the site of deposition of the antigen and cortisone in adequate dosage may inhibit this inflammatory reaction and thus interfere with a maximal antibody response $(27,28)$. During the course of these experiments, no clinical difference was observed in the local inflammatory response to the antigen in the cortisone-treated group as opposed to the control group. Moreover, there did not appear to be any relation between the severity of the local reaction and the subsequent antibody titre. The failure of cortisone to influence circulating antibody titres in man may be a reflection of dosage as well as a species difference.

The conflicting evidence on antibody formation in adrenalectomized animals is difficult to explain. Early studies $(2-4,6)$ were done on adrenalectomized animals not maintained on any specific replacement therapy and the protocols indicate a high post-operative mortality rate. Jaffe and Marine (2), however, noted that the increased antibody formation was apparent only if the antigen was given soon after adrenalectomy. With a six-week interval between adrenalectomy and immunization, there was no increase in antibody formation. The present studies are not strictly comparable to those carried out in adrenalectomized animals since paients with Addison's disease may conceivably have some functional adrenal cortical tissue. The finding that patients with adrenal insufficiency do not exhibit any impairment or increase in antibody formation is in agreement with the quantitative data obtained in animals by Eisen and associates
(5) and hemolysin formation as reported by Thatcher, Houghton, and Ziegler (8).

\section{SUM MARY}

1. Quantitative immunochemical studies have been carried out in man using pneumococcal capsular polysaccharides as antigens.

2. The 12 subjects used as controls showed the presence of C-antibody in all sera tested. The Cantibody remained relatively constant in spite of sizeable changes in antibody to the capsular polysaccharides. There is considerable variation in the antibody response from one individual to another. A large response to one antigen is not necessarily accompanied by a similar response to another antigen in the same individual. Maximum antibody titres are usually achieved by two weeks following immunization.

3. The five patients with adrenal insufficiency did not demonstrate any impairment of ability to form antibodies.

4. The eight patients with untreated rheumatoid arthritis and nine cortisone-treated patients with rheumatoid arthritis had similar antibody responses when observed over a period of four weeks.

5. Two patients with rheumatoid arthritis with previously elevated antibody titres showed no change in these titres on the acute or chronic administration of cortisone.

\section{REFERENCES}

1. Murphy, J. B., and Sturm, E., The lymphoid tissue and antibody formation. Proc. Soc. Exper. Biol. \& Med., 1947, 66, 303. 
2. Jaffe, H. L., and Marine, D., Effect of suprarenalectomy in rats on agglutinin formation. J. Infect. Dis., 1924, 35, 334.

3. Také, N. M., and Marine, D., The effect of suprarenalectomy in rabbits on hemolysin formation. J. Infect. Dis., 1923, 33, 217.

4. Perla, D., and Gottesman, J. M., Immunological studies in relation to the suprarenal gland. II. Hemolysin formation in suprarenalectomized rats. J. Exper. Med., 1928, 47, 723.

5. Eisen, H. N., Mayer, N. M., Moore, D. H., Tarr, R. R., and Stoerk, H. C., Failure of adrenal cortical activity to influence circulating antibodies and gamma globulins. Proc. Soc. Exper. Biol. \& Med., $1947,65,301$.

6. Khorazo, D., Agglutinin production in suprarenalectomized rats. J. Immunol., 1931, 21, 151.

7. Hektoen, L., and Curtis, A. R., The effect on antibody production of the removal of various organs. $\mathrm{J}$. Infect. Dis., 1915, 17, 409.

8. Thatcher, J. S., Houghton, B. C., and Ziegler, C. H., Effect of adrenalectomy and adrenal cortical hormone upon the formation of antibodies. Endocrinology, 1948, 43, 440.

9. Dougherty, T. F., White, A., and Chase, J. H., Relationship of the effects of adrenal cortical secretion on lymphoid tissue and on antibody titre. Proc. Soc. Exper. Biol. \& Med., 1944, 56, 28.

10. Dougherty, T. F., Chase, J. H., and White, A., Pituitary-adrenal cortical control of antibody release from lymphocytes. An explanation of the anamnestic response. Proc. Soc. Exper. Biol. \& Med., 1945, 58, 135.

11. Hammond, C. W., and Novak, M., Relation of adrenal cortical steroids to antibody release. Proc. Soc. Exper. Biol. \& Med., 1950, 74, 155.

12. Fischel, E. E., LeMay, M., and Kabat, E. A., The effect of adrenocorticotrophic hormone and X-ray on the amount of circulating antibody. J. Immunol., 1949, 61, 89.

13. DeVries, J. A., The effect of ACTH on circulating antibody levels. J. Immunol., 1950, 65, 1.

14. Bjørneboe, M., Fischel, E. E., and Stoerk, H., The effect of cortisone and adrenocorticotrophic hormone on the concentration of circulating antibody. J. Exper. Med., 1951, 93, 37.

15. Germuth, F. G., and Ottinger, B., Effect of 17-hydroxy-11-dehydrocorticosterone (E) and of ACTH on arthus reaction and antibody formation in the rabbit. Proc. Soc. Exper. Biol. \& Med., 1950, 74, 815.

16. Vollmer, E. P., and Samsell, E., Failure of adrenocortical extract to modify the immunity acquired by intact mice through the use of pneumococcal vaccine. Endocrinology, 1949, 45, 204.

17. Chase, J. H., Effect of adrenalectomy upon maintenance of titer to sheep erythrocytes in hyperimmunized mice. Bull. New York M. Coll., Flower \& 5th Ave. Hosps., 1947, 10, 13.

18. Saunders, R. H., Jr., and Adams, E., Changes in circulating leukocytes following the administration of adrenal cortical extract and adrenocorticotrophic hormone in infectious mononucleosis and chronic lymphatic leukemia. Blood, 1950, 5, 732.

19. Herbert, P. H., and de Vries, J. A., The administration of adrenocorticotrophic hormone to normal human subjects. The effect on the leukocytes in the blood and on circulating antibody levels. Endocrinology, 1949, 44, 259.

20. Sayers, G., Burns, T. W., Tyler, F. H., Jager, B. V., Schwarts, T. B., Smith, E. L., Samuels, L. T., and Davenport, H. W., Metabolic actions and fate of intravenously administered adrenocorticotrophic hormone in man. J. Clin. Endocrinol., 1949, 9, 593.

21. Mirick, G. S., The effects of ACTH and cortisone on antibodies in humans. Bull. Johns Hopkins Hosp., 1951, 88, 332.

22. Hahn, E. O., Houser, H. B., Rammelkamp, C. H., Jr., Denny, F. W., and Wannamaker, L. W., Effect of cortisone on acute streptococcal infections and poststreptococcal complications. J. Clin. Invest., 1951, 30, 274.

23. Heidelberger, M., and MacPherson, C. F. C., Quantitative micro-estimation of antibodies in the sera of man and other animals. Science, 1943, 97, 405.

24. Heidelberger, M., Quantitative chemical studies on complement or alexin. I. A method. J. Exper. Med., 1941, 73, 681.

25. Heidelberger, M., MacLeod, C. M., Kaiser, S. J., and Robinson, B., Antibody formation in volunteers following injection of pneumococci or their typespecific polysaccharides. J. Exper. Med., 1946, 83, 303.

26. Heidelberger, M., MacLeod, C. M., Hodges, R. G., Bernhard, W. G., and di Lapi, M. M., Antibody formation in men following injection of four typespecific polysaccharides of pneumococcus. J. Exper. Med., 1947, 85, 227.

27. Kabat, E. A., Wolf, A., and Bezar, A. E., Effect of cortisone on experimental acute disseminated encephalomyelitis. Federation Proc., 1951, 10, 412; J. Exper. Med., in press.

28. Blunt, J. W., Jr., Plotz, C. M., Lattes, R., Howes, E. W., Meyer, K., and Ragan, C., Effect of cortisone on experimental fractures in the rabbit. Proc. Soc. Exper. Biol. \& Med., 1950, 73, 678. 